\title{
STRATEGI CURIOSITY BASED LEARNING DALAM PEMBELAJARAN MENULIS TEKS ILMIAH POPULER DI KELAS VII SMP NEGERI 3 BANDUNG
}

\author{
Widaningsih, M.Pd. \\ Universitas Pendidikan Indonesia \\ widaningsih.hilman827@gmail.com
}

\begin{abstract}
Abstrak
Tulisan ini bermaksud mendeskripsikan perubahan keingintahuan peserta didik terhadap sumber informasi/pengetahuan atau ide tulisan dengan menerapkan strategi Curiosity Based Learning (CBL) dalam pembelajaran menulis teks ilmiah populer. Pemilihan strategi pembelajaran menulis yang terjadi tidak membangun konteks menulis sehingga isi tulisan peserta didik kering ide dan tidak informatif. Strategi pembelajaran yang diterapkan tidak membangun keingintahuan peserta didik terhadap berbagai sumber ide dan informasi. Berdasarkan hasil analisis data diperoleh hasil yang menunjukkan efektivitas penerapan strategi Curiosity Based Learning dalam meningkatkan keingintahuan peserta didik terhadap sumber ide dan informasi. Pada tahap selanjutnya, kemampuan menulis dan kualitas tulisan peserta didik lebih baik dan informatif dibandingkan dengan kelas yang tidak menggunakan strategi ini. Strategi Curiosity Based Learning (CBL) sangat tepat menjadi strategi pembelajaran menulis teks ilmiah populer.
\end{abstract}

Kata kunci: keingintahuan, kemampuan menulis, strategi Curiosity Based Learning, teks ilmiah populer

\begin{abstract}
This writing/thesis is intended to describe the change of students' curiosity on knowledge source or writing idea by applying Curiosity Based Learning (CBL) strategy in learning how to write popular scientific text. The choice of strategy for learning how to write happening does not construct writing context so the content of students' writing is lack of idea and uninformative. The learning strategy applied does not encourage students' curiosity on various idea and information sources. Based on the result of data analysis gained that the result shows the effectiveness of strategic application for CBL in increasing students' curiosity on idea and information sources. On next stage, the capability of writing and the quality of students' writing are getting better and more informative than the other classes which do not use this strategy. The strategy of Curiosity Based Learning is quite right for the
\end{abstract}


strategy of learning how to write popular scientific text.

Key words: curiosity, writing capability, strategy of Curiosity Based Learning, popular scientific text

\section{Pendahuluan}

Menulis merupakan keterampilan berbahasa yang produktif ekspresif. Keterampilan menulis ini merupakan perwujudan dari keterampilan membaca dan keterampilan menyimak yang baik. Keterampilan menulis menjadi jendela seberapa orang itu membaca dan menyimak informasi/pengetahuan. Keterampilan menulis juga menjadi istimewa karena jejaknya ada, berupa teks tulis, terabadikan. Menulis adalah upaya untuk menciptakan keabadian, dalam arti seseorang bisa meninggalkan kemanfaatan dalam jangka panjang. Masyarakat tentunya akan tetap menikmati hasil karyanya meski zaman dan generasi telah berganti (Suharjono, 2012:5).

Menulis berkaitan erat dengan teks. Teks adalah satuan bahasa yang dimediakan secara tulis atau lisan dengan tata organisasi tertentu untuk mengungkapkan makna dalam konteks tertentu. Ada dua unsur pembangun teks, yaitu konteks situasi dan konteks budaya. Halliday (dalam Emilia, 2011) mengatakan bahwa konteks situasi merupakan unsur paling kuat dampaknya terhadap penggunaan bahasa, yang terdiri atas tiga aspek, yakni filed, mode, dan tenor. Field mengacu pada topik atau kegiatan yang sedang berlangsung atau yang diceritakan dalam teks, apa yang terjadi. Tenor mengacu pada perangkat simbolik yang berfungsi menunjukkan atau menyiratkan hubungan penulis dengan pembacanya atau pembicara dengan pendengarnya. Mode mengacu pada pertimbangan apakah bahasa yang dipakai lisan atau tulisan, jarak antara orang yang berkomunikasi dalam ruang dan waktu, apakah bertemu muka atau terpisahkan ruang dan waktu (Emilia, 2011:5-6).

Sebuah tulisan atau teks digunakan untuk menyampaikan ide, pesan, pikiran, atau gagasan kepada pembaca. Ide atau gagasan ini menjadi sentral dalam keterampilan menulis. Hal ini pula yang menjadi sebab sulitnya menulis. Ketiadaan ide, gagasan yang akan ditulis menjadi alasan utama peserta didik atau siapa pun berhenti atau enggan menulis. Oleh karena itu, menjadi penting bagi para pendidik untuk mempelajari teknik membangun konteks agar pada tahap ini kuriositas peserta didik terlecutkan.

Membangun konteks atau proses membangun pengetahuan (building knowledge of the field) inilah yang harus dihadirkan dalam pembelajaran. Pada proses membangun pengetahuan ini peserta didik diajak untuk mengetahui, menggali, menelaah topik yang akan ditulisnya. Dengan kata lain, curiosity peserta didik terhadap sumber pengetahuan atau ide tulisan perlu dibangun. Untuk mencapai tahap terkumpulnya pengetahuan peserta didik akan menggunakan keterampilan berbahasa yang lainnya, yaitu menyimak, membaca, dan berbicara. (Emilia, 2011: 33)

Tahun 2013 Kementerian Pendidikan dan Kebudayaan menetapkan perubahan Kurikulum KTSP 2006 dengan Kurikulum 2013. Perubahan kurikulum ini juga menyentuh perubahan dalam metode pembelajaran yang harus dipilih guru agar dapat mencapai kompetensi yang diharapkan. Permendikbud Nomor 65 Tahun 2013 tentang Standar Proses Pendidikan dalam salinan Lampiran Permendikbud Nomor 65 Tahun 2013 tentang Standar Proses Pendidikan menjabarkan metodologi pembelajaran yang disarankan digunakan guru, yaitu metode berbasis projek/penemuan seperti pembelajaran berbasis pemecahan 
masalah, inquiry learning, dan discovery learning.

Strategi Curiosity Based Learning (CBL) merupakan model pembelajaran berbasis penemuan. Strategi ini memberikan ruang bagi peserta didik membangun konteks pengetahuan (faktual, konseptual, dan prosedural) berdasarkan rasa ingin tahunya melalui kegiatan observasi, investigasi, dan aquire. Curiosity sendiri adalah rasa ingin tahu yang tidak pernah merasa puas akan apa yang diketahuinya sekarang. Dengan menerapkan strategi ini (CBL) diharapkan pembelajaran menjadi tempat yang menyenangkan bagi tumbuhnya rasa ingin tahu peserta didik. Dengan terpenuhinya rasa ingin tahu ini, informasi yang diperoleh akan menjadi modal bagi peserta didik mengembangkan kemampuan menulisnya.

Sekaitan dengan kemampuan menulis ini, Syamsudin (2011:2) mengatakan bahwa menulis adalah kegiatan merangkai, menyusun secara cermat buah pikiran ke dalam bentuk tulisan yang beruntun dan teratur tentang suatu masalah. Tarigan mengatakan bahwa menulis ialah menurunkan atau melukiskan lambang-lambang grafik yang menggambarkan suatu bahasa yang dipahami oleh seseorang, sehingga orang lain dapat membaca lambang-lambang grafik tersebut. Menulis merupakan suatu representasi bagian dari kesatuan-kesatuan ekspresi bahasa" (Tarigan, 2008:22). Adapun Nurudin (2012:3) memberikan batasan menulis sebagai segenap rangkaian kegiatan seseorang dalam rangka mengungkapkan gagasan dan menyampaikannya melalui bahasa tulis kepada orang lain agar mudah dipahami.

Beberapa hal yang perlu digarisbawahi tentang menulis, yaitu gagasan, bahasa tulis tepat kaidah dan mudah dipahami, serta keteraturan organisasi tulisan. Semi berpendapat bahwa "keterampilan menggunakan bahasa tulis yang dimaksud adalah pemakaian semua unsur bahasa, yaitu ejaan, kata, ungkapan, kalimat, dan pengembangan paragraf yang digunakan dengan tepat dan efektif sesuai dengan tujuan, isi, dan latar belakang pembaca" (Semi, 2007: 42). Menulis berdasarkan penilaiannya sebagaimana diungkapkan Nurgiyantoro (2009) adalah bahwa penilaian keterampilan menulis analisis merinci karangan ke dalam kategori-kategori tertentu yang berbeda tergantung jenis karangannya. Kategori tersebut akan bervariasi sesuai dengan jenis karangan, kategori yang pokok meliputi (1) kualitas dan ruang lingkup isi, (2) organisasi dan penyajian isi, (3) gaya dan bentuk bahasa, (4) mekanik: tata bahasa, ejaan, tanda baca, kerapihan dan kebersihan tulisan, dan (5) respon afektif guru terhadap karangan (Zaini Machmud dalam Nurgiyantoro, 2009: 305).

Wade (2007:33-34) mengungkapkan bahwa "You need three basic abilities to write well on subjects with a factual basis: (a) a good research skills, (b) a balance of entertainment and fact, (c) an'angel' which is reader-friendly." (Dibutuhkan tiga kemampuan dasar untuk menulis yang baik tentang sesuatu yang berbasis faktual, yaitu: (a) keterampilan penelitian yang baik; (b) keseimbangan antara hiburan dan fakta; dan (c) sudut penulisan yang ramah baca). Riset yang baik akan mempengaruhi isi dan organisasi /penyajian karangan. Penelitian adalah tahap membangun konteks, yang di dalamnya ada langkah observasi, investigasi, dan pemerolehan pengetahuan faktual, konseptual, dan prosedural. Sampai di sini, terbukti bahwa strategi pembelajaran yang digunakan harus sesuai dengan tujuan pembelajaran. Dengan demikian, strategi yang tepat dalam pembelajaran menulis adalah pembelajaran berbasis riset seperti strategi Curiosity Based Learning (CBL).

Berdasarkan beberapa pedapat tentang menulis tersebut dapat disimpulkan bahwa kemampuan menulis adalah (a) kemampuan menuangkan dan menyusun ide/gagasan dengan runtut dan lengkap, (b) kemampuan menggunakan bahasa yang mudah dipahami 


\section{Strategi Curiosity Based Learning}

dengan tatabahasa yang tepat dan efektif, (c) kemampuan menyajikan karangan dengan organisasi tulisan yang teratur, (d) kemampuan menggunakan gaya/style, (e) kemampuan menggunakan ejaan dan tanda baca.

Karangan ilmiah populer atau teks ilmiah populer yang dimaksud dalam penelitian ini adalah karangan yang disusun secara sistematis dan bersifat menyampaikan pengetahuan yang disampaikan dengan bahasa sederhana dan santai, serta penyajian yang sederhana sehingga mudah dipahami. Ciri bahasa yang sederhana bisa dilihat dari penggunaan pilihan kata dan kalimat yang sederhana, tidak menggunakan istilah teknis, dan tidak menggunakan bahasa asing (Jauhari, 2013: 123).

Pengertian karangan/artikel ilmiah populer yang sejalan dengan Jauhari juga disampaikan oleh Mondry yang dikutip dari pendapat Supriyanto (1986) bahwa artikel ilmiah populer adalah tulisan yang menyajikan analisis ilmu pengetahuan umum yang ditulis secara menarik bagi pembaca. Tujuan pokoknya mempersempit jarak antara ilmuwan dengan masyarakat umum (2008:210).

Berdasarkan uraian tersebut maka ditetapkanlah parameter menulis teks ilmiah populer, yaitu

a) isi karangan, yang mencakup keluasan dan kedalaman isi/informasi yang disampaikan;

b) bahasa, ketepatan dan kefektifan tatabahasa yang digunakan;

c) organisasi/penyajian karangan, keteraturan dan kelogisan penyajian gagasan;

d) gaya tulisan, berhubungan dengan kreativitas dalam menampilkan keunikan, kebaruan, dan pendekatan pengembangan tulisan;

e) ejaan dan tanda baca, ketepatan dan kecermatan penggunaan ejaan dan tanda baca;

f) unsur teks ilmiah populer, bahasa dan penyajian sederhana sehingga mudah dipahami, isi penting (berhubungan dengan ilmu pengetahuan).

Parameter inilah yang akan peneliti gunakan dalam menilai karangan ilmiah populer yang dihasilkan oleh subjek penelitian.

Selanjutnya, strategi Curiosity Based Learning(CBL) yang dimaksud dalam penelitian ini adalah pembelajaran berbasis keingintahuan. Keingintahuan menurut Sumrongthong (Culalongkorn University, 2013) adalah "dorongan pikiran yang selalu ingin belajar lebih banyak tentang sesuatu atau suatu dorongan untuk menyelidiki (inkuir), meneliti (investigasi), atau mencari pengetahuan". Tentang keingintahuan ini Danim mengatakan bahwa setiap anak itu memiliki kebiasaan tertentu yang merupakan fenomena kembar. Ada kebiasaan buruk ada kebiasaan baik. Kebiasaan buruk di sini yang dapat diubah dalam pembelajaran, di antaranya adalah rasa ingin tahu (curiosity). Seorang peserta didik yang memiliki kebiasaan ini tidak pernah merasa puas akan apa yang telah diketahuinya sekarang, selalu mengembangkan rasa ingin tahu. Sebagian rasa ingin tahunya itu dipenuhinya dengan caranya sendiri, sebagian lagi diperolehnya dengan cara bertanya kepada pendidik atau orang dewasa (2011:16).

Peserta didik yang keingintahuannya berkembang sangat baik adalah pembelajar yang tekun, namun sering juga "menjengkelkan" ketika pendidik atau orang dewasa dijejali dengan pertanyaan yang aneh-aneh yang kadang sulit dijawab". Sejalan dengan pendapat tersebut menurut psikolog perkembangan dalam Hidalgo, rasa ingin tahu (curiosity) merupakan bagian penting dalam disposisi kompleks yang diperlukan untuk belajar sepanjang hayat. 
Karakteristik strategi Curiosity Based Learning (CBL) adalah (a) siswa memulai minat mereka pada sumber topik yang diminatinya, (b) pendidik dan peserta didik saling membantu memperoleh pengetahuan dari berbagai sumber, (c) membantu siswa menciptakan sebuah model belajar untuk masa depan mereka, (d) belajar melalui proses penilaian oleh teman sebaya, (Sumrongthong, 2013).

Adapun tujuan strategi Curiosity Based Learning (CBL) adalah (a) membaca dan mendengarkan dengan baik (read well and listen well), sebagai kegiatan awal (input informasi), (b) berpikir dengan baik (think well), merupakan proses analisis informasi, definisi masalah, dan generalisasi berbagai solusi, (c) berkomunikasi dengan baik (communicate well), sebagi tujuan akhir penerapan CBL yang meliputi kegiatan ekspresi lisan, penjelasan berbagai metode dan keterampilan sebagai pendengar yang baik/pelapor. (Sumrongthong, 2013)

Berikut ini langkah-langkah strategi Curiosity Based Learning(CBL): (1) Observasi dan eksplorasi tentang objek/materi/konsep; kemudian menyusun tulisan deskripsi tentang objek tersebut; (2) Investigasi hasil pengamatan dibandingkan dengan peserta didik lain dan ide-ide yang lain; (3) Aquire/pemerolehan pengetahuan lebih banyak dari berbagai sumber; (4) Membuat kategori dan visualisasi data diagram pengetahuan; (5) Menyampaikan presentasi dan laporan visual kepada teman; (6) Review/meninjau dan mendiskusikan hasil. (Sumrongthong, 2013)

Penerapan CBL dalam Pembelajaran Menulis Teks Ilmiah Populer adalah sebagai berikut.

TABEL 2.2

PENERAPAN CBL DALAM PEMBELAJARAN

\begin{tabular}{|c|c|c|}
\hline Na. & 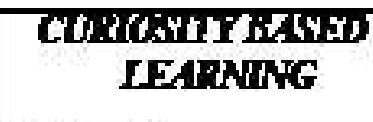 & $\begin{array}{l}\text { PEMETE AJARAN BENULS TEKS } \\
\text { II MIAH YOFOLER }\end{array}$ \\
\hline 1. & Oterereti & 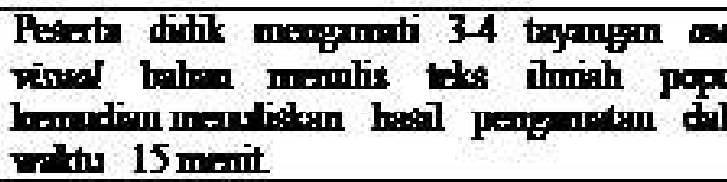 \\
\hline 2. & Inrestipasi & 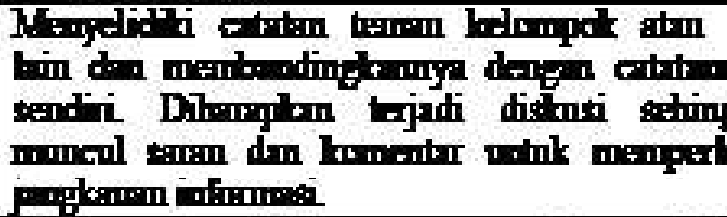 \\
\hline 3. & 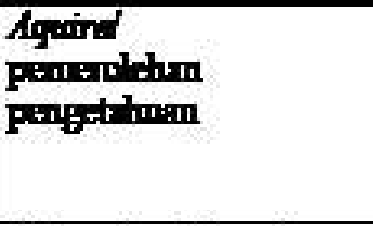 & 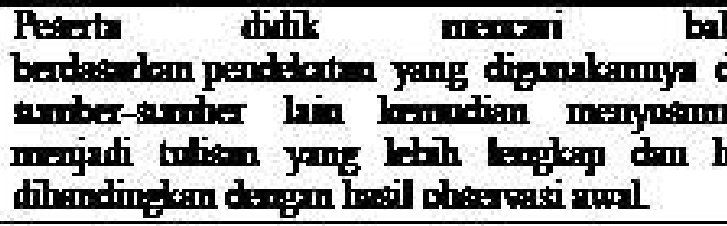 \\
\hline 4. & 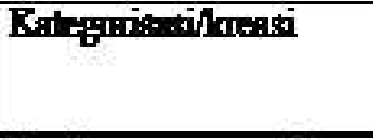 & 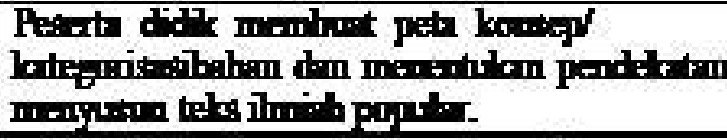 \\
\hline 5. & 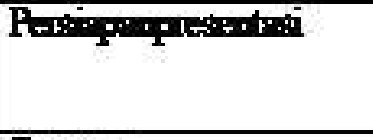 & 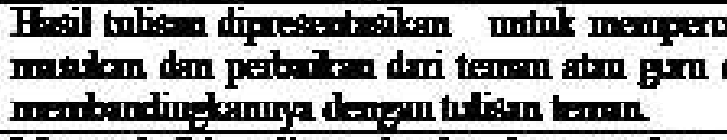 \\
\hline 6. & Phive & 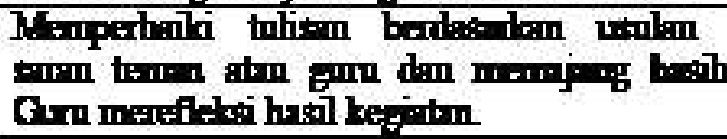 \\
\hline
\end{tabular}


Berdasarkan karakteristik strategi Curiosity Based Learning maka penulis menduga bahwa strategi ini akan dapat meningkatkan kemampuan menulis teks ilmiah populer peserta didik kelas VII SMP Negeri 3 Bandung dengan efektif.

Rumusan masalah yang akan dipecahkan melalui penelitian ini adalah memperoleh gambaran (a) profil kemampuan menulis teks ilmiah populer pada peserta didik Kelas VII SMPN 3 Kota Bandung; (b) profil proses pembelajaran menulis teks ilmiah populer pada peserta didik Kelas VII SMPN 3 Kota Bandung; (c) proses penerapan strategi Curiosity Based Learning(CBL) dalam pembelajaran menulis teks ilmiah populer di Kelas VII SMPN 3 Kota Bandung; (d) keefektifan strategi Curiosity Based Learning (CBL) dalam meningkatkan kemampuan menulis teks ilmiah populer peserta didik di Kelas VII SMPN 3 Kota Bandung.

Penelitian ini bertujuan menemukan (a) strategi yang tepat bagi pembelajaran menulis umumnya, khususnya pembelajaran menulis teks ilmiah populer, (b) keefektifan penerapan strategi ini dalam meningkatkan kemampuan menulis teks ilmiah populer dibandingkan dengan strategi yang selama ini digunakan guru, dan (c) bukti yang menguatkan bahwa untuk meningkatkan keterampilan menulis perlu dibangun konteks menulis bagi peserta didik.

\section{Metode Penelitian}

Metode yang digunakan dalam penelitian ini adalah metode eksperimen. Desainnya adalah quasy experimentalthe matching-only pretest-posttest control group design. Pada desain ini sampel kelas baik kelas eksperimen maupun kelas kontrol tidak ditentukan secara random (Sugiyono, 2012:79).

Prosedur penelitian yang ditempuh sebagai berikut. Langkah pertama yang peneliti lakukan dalam penelitian ini adalah menemukan masalah yang memiliki kebermanfaatan bagi pengembangan ilmu pengetahuan, utamanya di bidang yang peneliti geluti selama ini sebagai pendidik. Oleh karena itu, fokus utama penelitian ini berkisar pada perencanaan, proses, dan evaluasi pembelajaran.

Langkah kedua yang peneliti lakukan adalah studi pendahuluan, yaitu melakukan kajian teori/pustaka untuk mengungkap kemungkinan masalah yang diteliti sudah diteliti oleh peneliti lain dan mengungkap hasil penelitian tersebut, menguatkan masalah yang akan diteliti, dan menemukan hal-hal lain yang berkaitan dengan masalah yang akan diteliti.

Langkah ketiga peneliti menyusun instrumen tes dan nontes yang akan digunakan dalam pelaksanan penelitian. Instrumen yang telah disusun kemudian ditimbang oleh ahli. Kegiatan ini dilakukan untuk mendapatkan instrumen penelitian yang valid dan reliabel baik secara konten maunpun konstruk. Uji instrumen dilakukan dengan timbangan ahli dan uji statistik validitas dan reliabilitas. Instrumen yang digunakan adalah instrumen tes menulis teks ilmiah populer, pedoman penilaian menulis teks ilmiah populer, pedoman observasi pembelajaran, pedoman observasi aktivitas belajar peserta didik, instrumen angket respon peserta didik, dan pedoman wawancara.

Langkah keempat, pelaksanaan proses pembelajaran yaitu, (a) melakukan prates, baik terhadap kelas eksperimen maupun kelas kontrol, (b) melaksanakan pembelajaran menulis teks ilmiah populer dengan menggunakan strategi Curiosity Based Learning (CBL) pada kelas eksperimen sedangkan pada kelas kontrol dilakukan pembelajaran menggunakan strategi 
pembelajaran yang selama ini digunakan guru/ strategi terlangsung, dan (c) melakukan pascates terhadap kelas eksperimen dan kelas kontrol untuk mengetahui hasil kemampuan menulis teks ilmiah populer pascatindakan pada kelas eksperimen dan kelas kontrol.

Langkah terakhir dari penelitian ini adalah analisis hasil belajar dan hasil tindakan penerapan Curiosity Based Learning (CBL) dengan langkah kegiatan analisis (a) hasil prates dan pascates karangan ilmiah populer peserta didik dengan tiga penimbang (dua praktisi dan satu penimbang ahli) menggunakan rubrik penilaian menulis yang telah disusun dan menampilkan hasilnya secara deskriptif, (b) hasil observasi pembelajaran, aktivitas belajar peserta didik, angket respon peserta didik, dan hasil wawancara dengan guru, (c) hasil uji statistik, uji statistik yang digunakan adalah uji normalitas data, uji beda kemampuan awal, uji hipotesis penelitian dan uji efektivitas perubahan dan perbedaan kemampuan antara kelas eksperimen dengan kelas kontrol, dan (d) menetapkan hasil penelitian.

Populasi penelitian ini adalah peserta didik kelas VII SMP Negeri 3 Bandung dan sampel penelitian jatuh pada kelas VII-1 sebagai kelas eksperimen dan kelas VII-4 sebagai kelas kontrol. Jumlah kelas eksperimen dan kelas kontrol masing-masing adalah 32 peserta didik.

\section{Hasil Penelitian dan Pembahasan}

\subsection{Hasil Penelitian}

Profil strategi pembelajaran menulis umumnya menggunakan metode pemodelan dan penugasan. Dengan model ini kesempatan peserta didik membangun konteks menulis sangat sedikit. Keadaan ini berakibat pada kualitas tulisan peserta didik. Tulisan tidak informatif dan kurang nilai kebaruan. Pembelajaran menulis menjadi kegiatan yang sunyi dari gairah pencarian ilmu pengetahuan dan informasi. Peserta didik duduk dengan alat tulis di meja dan bingung mau menulis apa. Ide menjadi sesuatu yang sulit dicari. Akhirnya, tulisan/karangan disajikan berupa urutan kegiatan dan "curhat" peserta didik. Karangan peserta didik kemudian dinilai berdasarkan parameter kemampuan menulis yang telah disusun sebelumnya untuk melihat sejauh mana keingintahuan peserta didik terhadap

\begin{tabular}{|c|c|c|}
\hline No. & Aspek yang Dinilai & Bobot \\
\hline 1 & 2 & 3 \\
\hline 1 & $\begin{array}{l}\text { Isi } \\
\text { a. Empat jika isi padat informasi, pengembangan tuntas, relevan dengan } \\
\text { tema, nilai penting/kebermaknaan. } \\
\text { b. Tiga jika informasi cukup, pengembangan terbatas, relevan dengan } \\
\text { tema tetapi kurang lengkap, dan penting. } \\
\text { c. Dua jika informasi terbatas, pengembangan kurang tuntas, kurang } \\
\text { relevan dengan tema, dan kurang penting. } \\
\text { d. Satu jika tak berisi, pengembangan tidak tuntas, tidak relevan dengan } \\
\text { tema, tidak penting. }\end{array}$ & 6 \\
\hline 2. & $\begin{array}{l}\text { Bahasa } \\
\text { a. Empat jika tata bahasa benar, sangat sedikit kesalahan penggunaan, } \\
\text { kalimattidakambigu, penyusunan kalimat efektif, dan pilihan kata tepat. } \\
\text { b. Tiga jika penggunaan dan penyusunan kalimat benar, kalimat tidak } \\
\text { ambigu, sedikit kesalahan tatabahasa dengan tanpa mengaburkan } \\
\text { makna, penyusunan kalimat efektif dengan satu dua kesalahan, pilihan } \\
\text { kata hanya satu dua ketidaktepatan pilihan kata. }\end{array}$ & 5 \\
\hline
\end{tabular}


sumber pengetahuan. Berikut parameter kemampuan menulis teks ilmiah populer.

c. Dua jika kesulitan dalam penggunaan dan penyusunan kalimat, beberapa kalimat ambigu, kesalahan tatabahasa yang mengaburkan makna, beberapa kalimat kurang efektif, dan pilihan kata ada lebih dari 3 ketidaktepatan pilihan kata.

d. Satu jika tidak menguasai penggunaan dan penyusunan kalimat, kalimat ambigu, tidak komunikatif dan tidak cukup untuk dinilai.

\begin{tabular}{|c|c|c|}
\hline Na. & Acpekng I & Esher \\
\hline 3. & 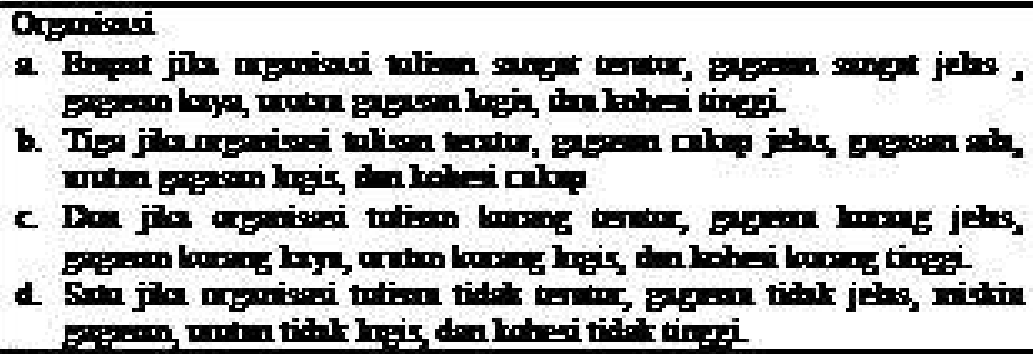 & 5 \\
\hline 4. & 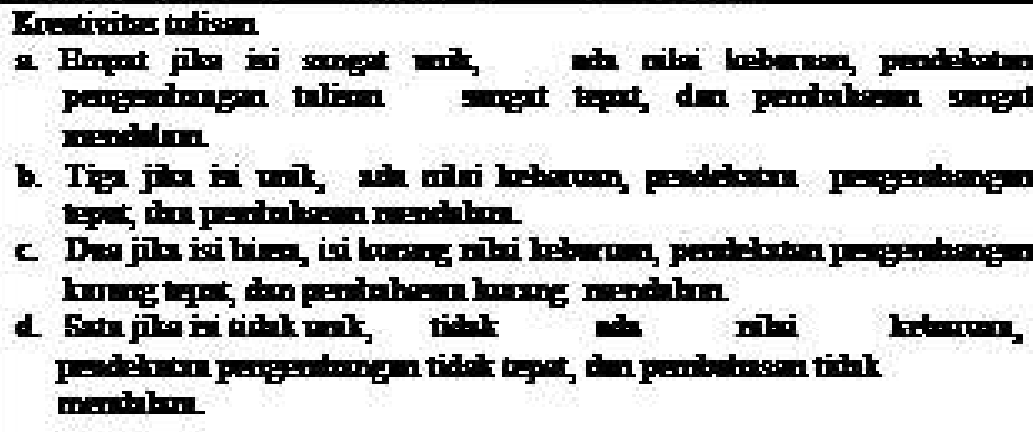 & 5 \\
\hline 5 & 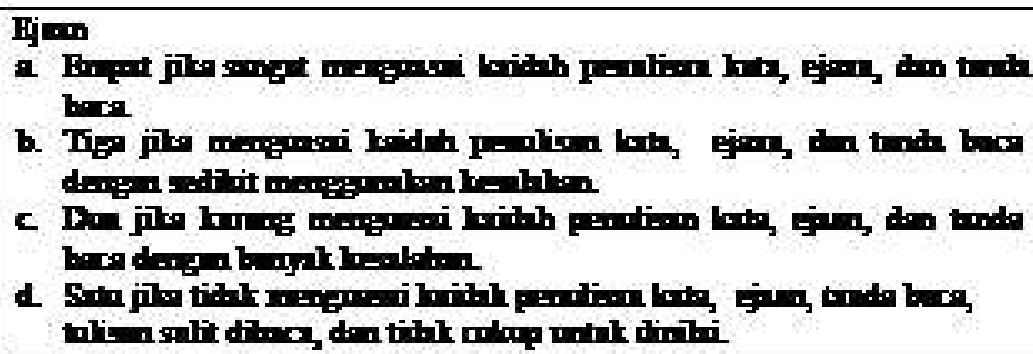 & 4 \\
\hline $\mathbf{6}$ & 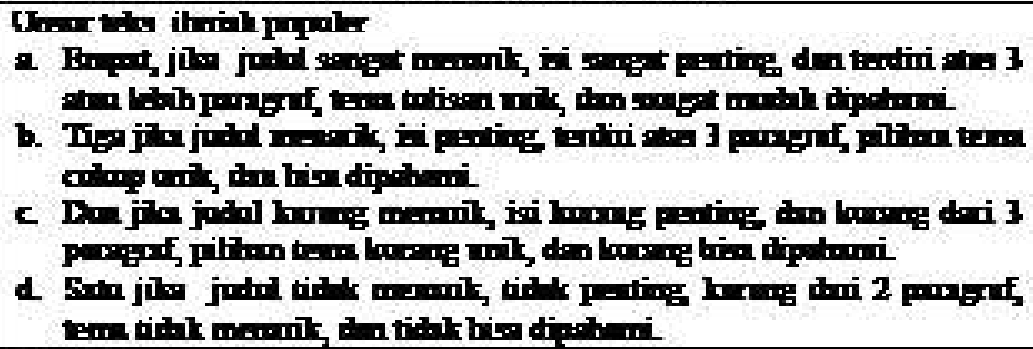 & $\mathbf{5}$ \\
\hline & Jumlah & 30 \\
\hline
\end{tabular}


Rata-rata kemampuan menulis berdasarkan parameter tersebut dari kedua kelompok sampel ini adalah 41,38 untuk kelas eksperimen dan 51,59 untuk kelas kontrol. Nilai ini berada pada kategori kurang

\begin{tabular}{|c|c|c|}
\hline No. & KAIEGORI & NIIAI \\
\hline 1. & 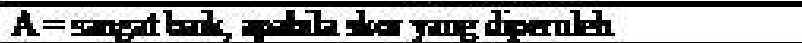 & B-100 \\
\hline $\mathbf{2}$ & 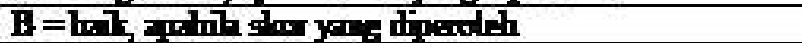 & $7-155$ \\
\hline 3. & 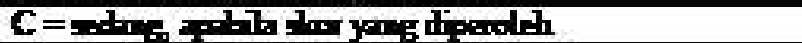 & $75-6$ \\
\hline 4. & 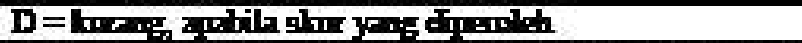 & $65-56$ \\
\hline 5. & 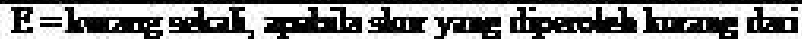 & 556 \\
\hline
\end{tabular}

TABEL 4.1

\section{KATEGORI NILAI MENULIS TEKS ILMIAH POPULER}

TABEL 4.2

\begin{tabular}{|c|c|c|c|c|c|}
\hline No. & \multicolumn{1}{|c|}{ Kategori } & $\begin{array}{c}\text { Jumlah } \\
\text { Resp. Eks }\end{array}$ & $\begin{array}{c}\text { Persenta } \\
\text { se }\end{array}$ & $\begin{array}{c}\text { Jumlah } \\
\text { Resp. } \\
\text { Kontrol }\end{array}$ & $\begin{array}{c}\text { Persenta } \\
\text { Se }\end{array}$ \\
\hline 1 & \multicolumn{1}{|c|}{2} & 3 & 4 & 5 & 6 \\
\hline 1. & $\begin{array}{l}\text { A = sangat baik, apabila skor } \\
\text { yang diperoleh 86-100 }\end{array}$ & - & & & \\
\hline 2. & $\begin{array}{l}\text { B = baik, apabila skor yang } \\
\text { diperoleh 76-85 }\end{array}$ & - & & 1 & $3,13 \%$ \\
\hline 3. & $\begin{array}{l}\text { C = sedang, apabila skor yang } \\
\text { diperoleh 66 - 75 }\end{array}$ & 2 & $6,25 \%$ & 3 & $9,39 \%$ \\
\hline 4. & $\begin{array}{l}\text { D = kurang, apabila skor yang } \\
\text { diperoleh 56-65 }\end{array}$ & 1 & $3,13 \%$ & 4 & $12,5 \%$ \\
\hline 5. & $\begin{array}{l}\text { E = kurang sekali, apabila skor } \\
\text { yang diperoleh kurang dari 56 }\end{array}$ & 29 & $90,63 \%$ & 24 & $75 \%$ \\
\hline & \begin{tabular}{l} 
Jumlah \\
\hline
\end{tabular} & 32 & $100 \%$ & 32 & $100 \%$ \\
\hline
\end{tabular}

\section{PERSENTASE TINGKAT KEMAMPUAN MENULIS TEKS ILMIAH POPULER PRATEST}

Berdasarkan gambaran tersebut, tingkat kemampuan awal menulis teks ilmiah populer peserta didik Kelas VII SMP Negeri 3 Bandung dengan kategori kemampuan kurang dan kurang sekali di atas angka 85\%, bahkan di kelas eksperimen mencapai angka 95\%. Dengan demikian, kemampuan awal menulis teks ilmiah populer kelas VII SMPN 3 Bandung masih sangat rendah.

Selanjutnya, kelas eksperimen diberi tindakan strategi Curiosity Based Learning. Berdasarkan hasil observasi terhadap proses pembelajaran dan aktivitas belajar peserta didik menunjukkan keadaan yang menggembirakan. Peserta didik sangat antusias mengikuti langkah pembelajaran yang dilaksanakan guru dari awal tindakan hingga akhir tindakan (5 kali pertemuan). Berdasarkan catatan pengamatan, intensitas peserta didik bertanya lebih baik dibandingkan sebelumnya. Peserta didik merespon dengan baik langkah-langkah pembelajaran yang diterapkan dengan antusias. Kelas menjadi hidup dengan pertanyaan dan diskusi peserta didik.

Hasil angket respon peserta didik terhadap penerapan strategi Curiosity Based Learning sangat positif. Berikut hasil rekapitulasi angket respon peserta didik terhadap penerapan strategi Curiosity Based Learning. 
Tabel 4.3 Rekapitulasi Hasil Angket Respon Siswa

\begin{tabular}{|c|c|c|c|c|c|}
\hline \multirow{2}{*}{ No. } & \multirow{2}{*}{ Pertanyaan } & \multicolumn{2}{|c|}{ Jawaban } & \multirow{2}{*}{$\begin{array}{l}\text { Abs } \\
\text { tain }\end{array}$} & \multirow{2}{*}{ Ket. } \\
\hline & & Ya & Tidak & & \\
\hline 1 & 1 & \multicolumn{3}{|c|}{3} & 4 \\
\hline 1. & $\begin{array}{l}\text { Apakah munurutmu pembelajaran menulis itu } \\
\text { sulit? }\end{array}$ & 8 & 22 & & $\mathrm{D}$ \\
\hline 2. & $\begin{array}{l}\text { Apakah menurutmu pembelajaran menulis itu } \\
\text { penting? }\end{array}$ & 30 & & & $\mathrm{D}$ \\
\hline 3. & $\begin{array}{l}\text { Apakah menurutmu pembelajaran menulis teks } \\
\text { ilmiah popular itu penting? }\end{array}$ & 30 & & & $\mathrm{D}$ \\
\hline 4. & $\begin{array}{l}\text { Apakah kamu suka model pembelajaran } \\
\text { menulis teks ilmiah popular dengan mencari, } \\
\text { menemukan, membaca, dan mendengar sendiri } \\
\text { informasi yang dibutuhkan? }\end{array}$ & 29 & 1 & & I \\
\hline 5. & 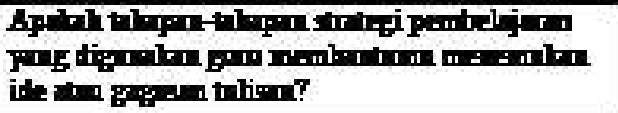 & 9 & I & & $\bar{I}$ \\
\hline 6 & 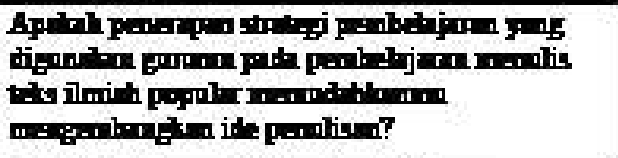 & $\boldsymbol{y}$ & 3 & & $\mathbf{1}$ \\
\hline 7. & 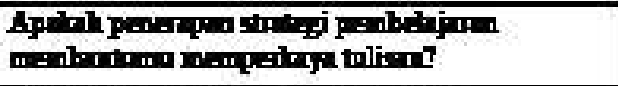 & $\overline{\mathbf{x}}$ & $\overline{3}$ & & $\overline{\mathbf{J}}$ \\
\hline 8 & 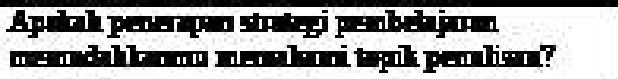 & $\overline{\mathbf{X}}$ & 3 & & I \\
\hline 9. & 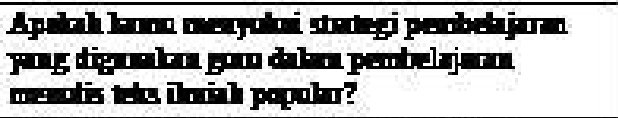 & $\boldsymbol{z}$ & & 1 & ] \\
\hline 10. & 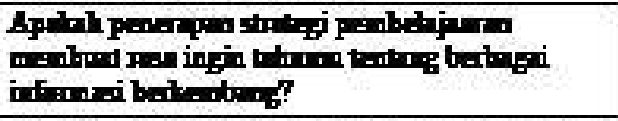 & 30 & & & ] \\
\hline 11. & 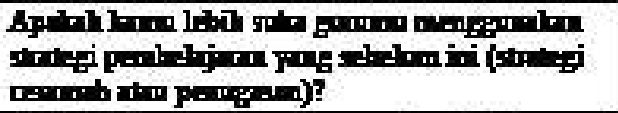 & 11 & 19 & & ] \\
\hline 12. & 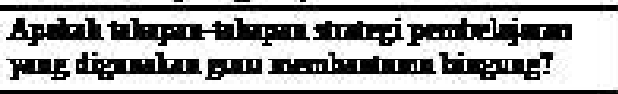 & 7 & 23 & & $\mathbf{J}$ \\
\hline
\end{tabular}

Berdasarkan tabel rekapitulasi hasil angket respon peserta didik di atas tampak bahwa respon peserta didik terhadap penerapan strategi Curiosity Based Learning sangat positif. Hal ini tampak dari respon peserta didik yang menganggap pembelajaran menulis itu tidak sulit seperti anggapan sebelumnya sebelum tindakan dilakukan (22 dari 30 peserta didik menjawab mudah untuk menulis) dan semua peserta didik menjawab penting tentang pembelajaran menulis. Ini adalah modal yang berharga bagi berkembangnya kemampuan menulis dan motivasi untuk menulis. Bahkan, respon peserta didik terhadap pertanyaan tentang penerapan CBL sangat baik. Dengan demikian, pada tahap ini tahap membangun konteks pengetahuan (faktual, konseptual, dan prosedural) dalam pembelajaran menulis 
teks ilmiah populer terhitung berhasil. Tahap ini adalah awal munculnya keingintahuan peserta didik. Jika proses ini dilakukan terus-menerus, dapat dipastikan bahwa keingintahuan peserta didik terhadap pengetahuan (faktual, konseptual, dan prosedural) atau konteks tersebut hasilnya akan lebih baik dan semakin baik. Terdapat fenomena yang menarik pada respon siswa terhadap strategi pembelajaran yang diterapkan guru sebelumnya. Respon peserta didik positif walaupun prosentasenya masih lebih baik respon terhadap penerapan strategi CBL.

Berikut ini disajikan data perkembangan keingintahuan peserta didik terhadap sumber tulisan (pengetahuan faktual, konseptual, dan prosedural) pada saat penerapan strategi Curiosity Based Learning (CBL).

\section{Perkembangan Curiosity Peserta Didik}

Berdasarkan grafik tersebut tampak perubahan keingintahuan peserta didik Kelompok Eksperimen terhadap sumber ide tulisan dilihat dari hasil tulisan yang dibuat. Pada keadaan sebelum tindakan, baik Kelas Eksperimen maupun Kelas Kontrol menunjukkan respon

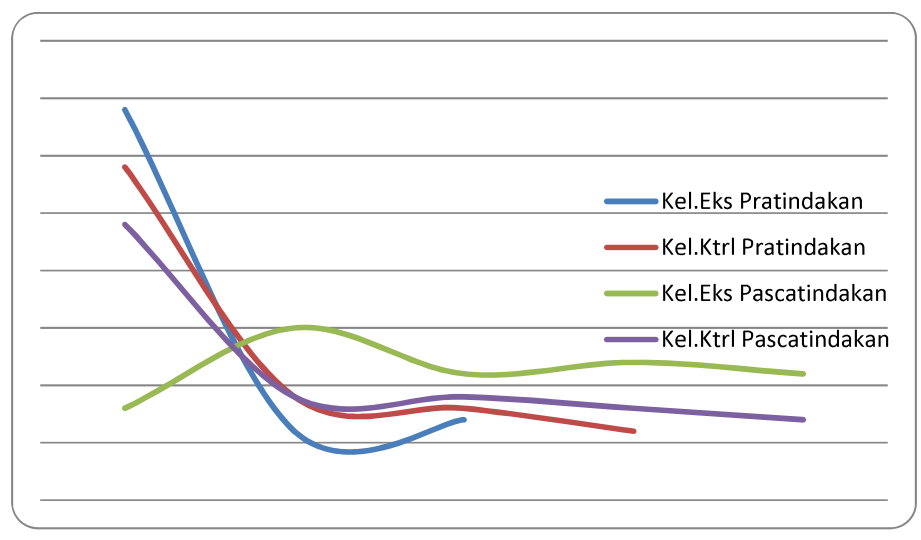

yang kurang terhadap sumber tulisan, keingintahuan peserta didik belum berkembang. Ini tampak pada hasil tulisan mereka yang tidak memenuhi kriteria parameter menulis yang digunakan, baik hasil penilaian dari penilai 1, 2, maupun penilai ahli. Hasilnya, 85\%-95\% berada pada kategori rendah s.d. rendah sekali (lihat garis biru dan merah pada grafik). Dengan kata lain, posisi peserta didik lebih banyak berada pada keadaan yang statis (kategori sangat kurang) terhadap sumber ide tulisan.

Adapun pascatindakan keingintahuan peserta didik menjadi semakin baik. Perhatikan garis hijau pada grafik untuk Kelas Eksperimen, yang menunjukkan perubahan keingintahuan peserta didik terhadap sumber ide/pengetahuan menjadi lebih ingin tahu. Pada Kelas Kontrol terdapat perubahan keingintahuan peserta didik terhadap sumber ide/pengetahuan, namun perubahan tersebut masih lebih rendah dibandingkan dengan perubahan keingintahuan pada Kelompok Eksperimen. Prosentase perubahan keingintahuan terhadap sumber ide/pengetahuan ini masih dalam tahap sedang (masih terdapat sekitar $20 \%$ s.d $30 \%$ peserta didik berada pada kategori kurang sampai dengan kurang sekali. Akan tetapi, jika dibandingkan dengan hasil pada awal tindakan perubahan ini cukup signifikan (dari $85 \%$ s.d. $95 \%$ pada kategori kurang dan kurang sekali menjadi $20 \%$ s.d $30 \%)$. Perubahan respon terhadap sumber ide/pengetahuan yang baik ini baru pada satu siklus tindakan.

Berdasarkan hasil wawancara dengan peserta didik tentang kesan setelah 
pembelajaran dengan strategi Curiosity Based Learning (CBL), mereka mengemukakan bahwa dengan langkah pembelajaran yang dilakukan, mereka menjadi lebih ingin mengetahui berbagai informasi/pengetahuan. Mereka mendapat kesan menyenangkan dan menjadi lebih mudah menulis karena mempunyai ide untuk menulis. Beberapa peserta didik menjawab bahwa dengan strategi CBL ini mereka menjadi lebih mudah menulis, tulisan lebih rapi dan kesalahan penulisan (ejaan dan tanda baca) berkurang. Peserta didik menikmati pembelajaran dengan rileks.

Hasil wawancara dengan guru juga menunjukkan tanggapan yang sangat positif. Kendala utama penerapan strategi ini adalah harus didukung dengan ketersediaan sumber belajar yang beragam sehingga pelaksanaan langkah-langkah pembelajaran strategi Curiosity Based Learning dapat berjalan dengan baik. Berikut beberapa hal positif yang penerapan strategi Curiosity Based Learning berdasarkan hasil wawancara dengan guru model.

a) Peserta didik tidak kesulitan menemukan gagasan/topik tulisan karena bisa dari hal yang sederhana yang ada di sekeliling mereka. Dengan sentuhan informasi penting tentang topik tersebut, sentuhan nilai kebaruan, dan keunikan maka jadilah tulisan yang menarik dan informatif.

b) Peserta didik lebih termotivasi mengeksplor bahan/sumber tulisan sehingga dengan sendirinya mereka termotivasi membaca bahan yang terkumpul.

c) Peserta didik menjadi jeli mencari topik tulisan.

d) Peserta didik termotivasi membuat tulisan yang menarik (pada tahap visualisasi) sehingga tidak asal membuat tulisan.

e) Proses latihan menulis tidak satu kali, ada kegiatan menulis bersama dan menulis secara mandiri.

Hasil tulisan peserta didik setelah tindakan menunjukkan perubahan yang signifikan. Perubahan ini karena tahap membangun konteks menulis berhasil terjadi dalam proses pembelajaran dengan strategi Curiosity Based Learning. Strategi ini terbukti memberikan ruang bagi tumbuhnya keingintahuan peserta didik terhadap berbagai pengetahuan faktual/ konseptual/prosedural yang menjadi sumber tulisan (karangan ilmiah populer).

Hasil uji statistik menunjukkan hasil bahwa penerapan strategi CBL dan strategi terlangsung sama-sama efektif meningkatkan kemampuan menulis teks ilmiah populer.

TABEL 4.5

\section{SIMPULAN HIPOTESIS PENELITIAN}

\subsection{Pembahasan}

Menulis merupakan keterampilan berbahasa yang kompleks karena melibatkan kemampuan berbahasa vang lain, terutama menvimak dan membaca. Keterampilan

\begin{tabular}{|c|c|c|}
\hline Fo. & Hilporks & सAपILU \\
\hline 1. & 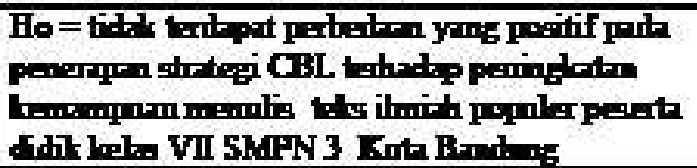 & Ditnth \\
\hline 2. & 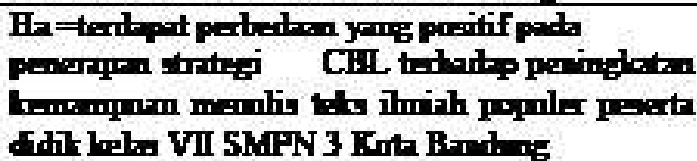 & Dilsima \\
\hline
\end{tabular}


menulis mencakup kemampuan menguasai gagasan yang akan dikemukakan, kemampuan menggunakan unsur-unsur bahasa, kemampuan menggunakan bentuk karangan, kemampuan menggunakan gaya, dan kemampuan menggunakan ejaan dan tanda baca (Rusyana dalam Syihabuddin, 2008:250). Keterampilan menulis menuntut pengalaman, waktu, kesempatan, pelatihan, keterampilan-keterampilan khusus dan pengajaran langsung menjadi seorang penulis. Menuntut gagasan tersusun secara logis, diekspresikan dengan jelas, dan ditata secara menarik. Keterampilan ini hanya dapat diperoleh melalui pelatihan yang terus-menerus dan berkelanjutan.

Begitu kompleksnya keterampilan menulis sehingga diperlukan sebuah strategi yang tepat agar kemampuan tersebut dapat dikuasai peserta didik melalui pelatihan yang terjadi di dalam pembelajaran. Menimbang bahwa keterampilan menulis erat kaitannya dengan tingkat kognitif seseorang (penguasaan gagasan/informasi/pengetahuan) keterampilan menulis menuntut penelitian yang terperinci, observasi yang saksama, pemilihan judul, bentuk, dan gaya yang tepat (Tarigan, 2008:9), strategi yang sesuai dengan keterampilan menulis adalah strategi Curiosity Based Learning. Strategi ini dipilih sebagai solusi agar peserta didik mendapat ruang mengembangkan dan membangun konteks dalam menulis (penguasaan gagasan atau field). Dalam langkah strategi Curiosity Based Learning terdapat tahap aquire/pemerolehan informasi dari berbagai sumber. Langkah ini sangat tepat bagi kegiatan membangun konteks menulis yang selama ini terabaikan dalam proses pembelajaran. Setelah peserta didik menikmati proses pembelajaran dengan strategi ini, lambat laun namun pasti keingintahuannya akan tumbuh dan motivasi internal belajar mandiri dalam diri peserta didik akan terbangun. Pada dasarnya manusia akan terus berupaya memenuhi kebutuhannya sampai terpuaskan (teori kebutuhan Maslow).

Dengan demikian, keingintahuan sangat penting bagi konteks menulis. Peserta didik akan lebih mudah menemukan ide untuk menulis karena dengan keingintahuan yang berkembang, hal sederhana yang awalnya diabaikan sebagai ide tulisan menjadi sesuatu yang menarik dikembangkan dalam sebuah tulisan. Keingintahuan akan mendorong peserta didik untuk mencari jawaban atas ketidaktahuannya. Hal ini sejalan dengan pengertian yang dikemukakan Edelman (1997) bahwa curiosity (kuriositas) adalah kebutuhan, rasa haus atau keinginan akan pengetahuan. Rasa ingin tahu (curiosity) ini merupakan awal dari akuisisi pengetahuan. Berlyne (1960) meyakini bahwa kuriositas merupakan prasyarat motivasi untuk perilaku eksplorasi. Eksplorasi sendiri mengacu pada segala kegiatan mengumpulkan informasi tentang lingkungan atau pengetahuan. Sementara itu pengertian strategi Curiosity Based Learning (CBL) menurut Sumrongthong (Culalongkorn University, 2013) adalah "dorongan pikiran yang selalu ingin belajar lebih banyak tentang sesuatu atau suatu dorongan untuk menyelidiki (inuir), meneliti (investigasi), atau mencari pengetahuan".

Hasil penelitian ini menjadi alat argumentasi peneliti bahwa asumsi-asumsi yang dijadikan landasan dalam kerangka berpikir peneliti tentang perlunya strategi yang tepat dan cocok akan menjadi solusi jitu bagi permasalahan yang terjadi dalam pembelajaran adalah benar adanya. Hal ini pula yang menjadi alasan pemilihan strategi Curiosity Based Learning dalam mengatasi permasalahan rendahnya kemampuan menulis peserta didik. Beberapa alasan yang mendasari pemilihan strategi Curiosity Based Learning adalah: (1) kemampuan menulis sangat ditunjang oleh kemampuan membaca, (2) kemampuan menulis akan meningkat jika latihan dilakukan secara terus-menerus sehingga pembelajaran yang cocok adalah pembelajaran berbasis penelitian seperti CBL ini, (3) dalam langkah CBL terdapat langkah kegiatan pemerolehan dari berbagai sumber bahan menulis karena 
kemampuan menulis harus ditunjang dengan kemampuan riset yang baik, (4) tujuan dari pembelajaran CBL adalah membentuk peserta didik menjadi pembaca yang baik, pendengar yang baik (sebagai input informasi), dan berpikir dengan baik (analisis data/informasi), dan (5) rasa ingin tahu peserta didik pada usia kelas VII ini dengan tingkat kognitif yang makin berkembang harus terus diberi ruang agar menjadi bekal baginya menjadi pembelajar handal sepanjang hayat. Inilah alasan strategi CBL ini dipilih sebagai strategi yang cocok bagi pembelajaran menulis pada tahap kegiatan membangun konteks.

Berdasarkan pernyataan tersebut, tampak bahwa strategi Curiosity Based Learning (CBL) sebagai salah satu strategi pembelajaran berbasis penelitian bersesuaian dengan proses pembelajaran yang disarankan dalam standar proses Kurikulum 2013. Strategi Curiosity Based Learning bisa menjadi alternatif strategi pembelajaran berbaisis projek/ penemuan dan memperkaya strategi yang sudah ada seperti discovery based learning, inquiry based learning, problem based learning, dan heuristika.

\section{Penutup}

Strategi Curiosity Based Learning dapat meningkatkan kemampuan menulis teks ilmiah populer secara efektif. Kualitas karangan peserta didik berubah secara signifikan dengan adanya ruang bagi tumbuhnya keingintahuan peserta didik sebagai modal memperoleh pengetahuan (faktual, konseptual, dan prosedural) sehingga tahap membangun konteks dapat terjadi secara optimal.

Berdasarkan kesimpulan tersebut, disarankan agar strategi Curiosity Based Learning digunakan dalam pembelajaran menulis. Apalagi dengan diberlakukannya Kurikulum 2013 yang capaian akhir dari pembelajaran adalah keterampilan menulis (berbagai jenis teks) dan membaca berbagai sumber maka strategi Curiosity Based Learning adalah pilihan yang tepat.

\section{Daftar Pustaka}

A.R., Syamsudin. 2011. Dari Ide, Bacaan, Simakan, Menuju Menulis Efektif, Teori, Teknik, Redaksi. Bandung: Geger Sunten. 
Alwasilah, A. Ch dan Alwasilah, S. 2007. Pokoknya Menulis. Bandung: Kiblat Buku Utama.

Danim, S. 2011. Perkembangan Peserta Didik. Bandung: Alfabeta.

Emilia, E. 2011. Pendekatan Genre Based dalam Pengajaran Bahasa Inggris: Petunjuk untuk Guru. Bandung: Rizqi Press.

Fraenkel, J. R., at al. 2011. How to Design and Evaluate Research in Education. Mc Graw Hill.

Jauhari, H. 2013. Terampil Mengarang. Bandung: Pustaka Cendikia.

Nurgiyantoro, B. 2009. Penilaian dalam Pengajaran Bahasa dan Sastra, Edisi Ketiga. Yogyakarta: BPFE.

Nurudin. 2012. Dasar-Dasar Penulisan. Malang: UMM Press.

Mondry. 2008. Pemahaman Teori dan Praktik Jurnalistik. Bogor: Ghalia Indonesia.

Semi, M. A. 2007. Dasar-Dasar Keterampilan Menulis. Bandung: Angkasa.

Sugiyono. 2012. Metode Penelitian Kuantitatif, Kualitatif, dan R\&D. Bandung: Alfabeta.

Sugiyono. 2012. Statistika untuk Penelitian. Bandung: Alfabeta.

Suharjono, B. 2012. Sukses Menjadi Penulis. Depok: Oncor Semesta Ilmu.

Syihabuddin. 2008. Evaluasi Pengajaran Bahasa Indonesia. Bandung: Sekolah Pascasarjana UPI.

Tarigan, H. G. 2008. Menulis, sebagai Suatu Keterampilan Berbahasa. Bandung: Angkasa.

Wade, S. 2007. Creative Writing, a Straight Forward Guide. Brighton BN2 4EG: Straightforward Publishing.

Wardoyo, S. M. 2013. Pembelajaran Berbasis Riset. Jakarta: Akademia Permata.

Paulo J. Hidalgo .2012. "Curiosity Based Learning and Self-Education." [http:// serc.carleton.edu/integrate/workshops/methods2012/essays/hidalgo. html], diakses 25 Januari 2013, pukul 13.30 WIB.

Sumrongthong, Bussakorn. 2013. "Etnomusikologi, Pendidikan, Terapi Musik. Curiosity-Based Learning (CBL) Program." Departemen Musik, Fakultas Seni Rupa dan Terapan, Universitas Chulalongkorn Bangkok 10330, Thailand), [http://issuu.com/gfbertini/docs/curiosity-based_learning_-_presentation], diakses 24 Januari 2013, pukul 21.00 WIB.

Sumrongthong, Bussakorn. 2013. "Curiosity-Based Learning." [http://wikibin. org/articles/ curiosity-based-learning.html], diakses 25 Januari 2013, pukul 13.35 WIB.

Edelman, Susan. 1997. Curiosity and Exploration. California State University, Northridge

[http://www.csun.edu / vcpsy00h/ students/explore.html], diakses pada 25 Januari 2013, pukul 13.40 WIB. 